\title{
ASPEKTI KOLABORATIVNE KREATIVNOSTI U NASTAVI GLAZBE U OSNOVNOJ ŠKOLI
}

\section{Jelena Martinović-Bogojević}

Muzička akademija, Univerzitet Crne Gore,

Cetinje, Crna Gora

jelena.bo@ucg.ac.me

Primljeno: 11. 12. 2019.

Socio-kulturološka dimenzija kreativnosti nezaobilazni je aspekt u teorijskim razmatranjima fenomena glazbene kreativnosti. Empirijska istraživanja i iskustva iz prakse dovela su do potrebe za rekonceptualizacijom $i$ reinterpretacijom pojma glazbene kreativnosti $u$ obrazovanju. Upravo se kroz socio-kulturološki kontekst razvio $i$ pojam 'kolaborativna kreativnost' (eng. collaborative creativity). Uškolskoj praksi kolaborativna se kreativnost može ostvariti među učenicima, ali i među nastavnicima koji surađuju kroz realiziranje integrativne nastave, izvannastavnih aktivnosti i projektne nastave. $U$ ovom radu predstavit će se neki oblici poticanja kolaborativne glazbene kreativnosti, s posebnim osvrtom na iskustvo učenika i utjecaj koji su zajednički stvaralački procesi imali na njihovu socijalizaciju, motivaciju, ali $i$ na praktičnu primjenu usvojenih znanja. Za metodološki okvir iskorišteno je akcijsko istraživanje provedeno u jednom odjeljenju petog razreda osnovne škole tijekom školske godine 2017./2018. Cilj rada je otvoriti pitanja o mogućnostima poticanja kolaborativne kreativnosti u redovitoj nastavi glazbe, ali i ukazati na objektivne poteškoće za realizaciju ovog oblika kreativnog procesa u školskim uvjetima.

Ključne riječi: kolaborativna kreativnost, glazbena kreativnost, nastava glazbe, osnovna škola 


\section{Uvod*}

Veza između kreativnosti i obrazovanja istraživana je u psihologiji i pedagogiji još od vremena kada je Guilford (1950) apostrofirao nedovoljno razvijanje divergentnog mišljenja u američkim školama, preko diferencijacije kreativnog učenja i kreativnog podučavanja, pa do recentnih teorija koje kategoriziraju četiri vrste kreativnosti: »Veliku K«, »Pro $\mathrm{k} «$, »malu k« $\mathrm{i} »$ mini $\mathrm{k}$ « $^{1}$ kreativnost, od kojih se posljednje dvije posebno razvijaju u obrazovanju (Kaufman i Beghetto, 2009).

Proširivanje pogleda na ovaj složeni konstrukt donose nove paradigme u drugoj polovini 20. stoljeća pa se tako vjeruje da svaka individua posjeduje kreativni potencijal. U posljednjim desetljećima razvijene su i teorije o tome da kreativna može biti i grupa sudionika koja stvara zajednički produkt. Glăveanu (2010) precizira tri paradigme u objašnjavanju fenomena kreativnosti: »On paradigmu«, »Ja paradigmu « $\mathrm{i} » \mathrm{Mi}$ paradigmu«. Upravo se posljednja odnosi na promatranje kreativnosti kroz sociološku prizmu te njeno izražavanje u grupnim procesima.

Shvaćanje kreativnosti kao nečega što ne pripada samo rijetkim pojedincima dovelo je do intenzivnije dinamike, kako istraživanja kreativnosti, tako i pronalaženja praktičnih načina za njeno razvijanje. Rhodes (1961) je odredio četiri glavna pristupa u proučavanju kreativnosti: kreativnu personu, kreativni proces, kreativni produkt i pritisak, stvorivši 4 P's Model of Creativity.

Međutim, dva osnovna polazišta u istraživanjima su temeljno podijeljena na orijentiranost na produkt i orijentiranost na proces. Oni koji se zalažu za orijentiranost na produkt kreativnost vide kao stvaranje nečega novog i istovremeno prikladnog (Sternberg i Lubart, 1999). Produkt podrazumijeva originalnost i inovativnost, koja može biti nova za samog stvaratelja, ali i nova za domenu ukoliko se radi o velikoj

* Istraživanje je provedeno školske godine 2017./2018. u okviru Interdisciplinarnih doktorskih studija za humanističke i društvene znanosti, područje Glazbena pedagogija na Sveučilištu u Ljubljani, pod mentorstvom prof. dr. Branke Rotar Pance. U ovome radu objavljujemo dio rezultata vezanih uz akcijsko istraživanje, a povezanih s provođenjem kolaborativne kreativnosti u pedagoškoj praksi.

${ }^{1}$ Kaufman i Beghetto (2009) kreiraju Four-C Model of Creativity kojeg čine: Big C, Pro $c$, little $c$, mini $c$ kreativnost. Big $C$ kreativnost pripisuje se rijetkim pojedincima koji donose nešto novo kulturi ili mijenjaju određeno područje. Pro $c$ kreativnost se odnosi na profesionalnu kreativnost, dok su little $c$ i mini $c$ kreativnost vezane za svakodnevnu kreativnost koju većina ljudi posjeduje. 
kreativnosti ili profesionalnoj kreativnosti (Kaufman i Beghetto, 2009). Drugi pristup orijentiran je na proces, a samim time i na značaj razvoja mišljenja, generiranja ideja, rješavanja problema i izražavanja individualnosti (Lin, 2011). Upravo je kreativne procese važno provoditi kroz obrazovanje na nižim stupnjevima kako bi se djeci omogućilo razvijanje kognitivnih vještina, ali i samopouzdanje kroz slobodno izražavanje svojih ideja. Lin (2011) dalje objašnjava distinkciju između kreativnog podučavanja (eng. teaching creatively) i podučavanja za kreativnost (eng. teaching for creativity) koje su u Velikoj Britaniji precizirane u dokumentu National Advisory Committee on Creative and Cultural Education (NACCCE, 1999). Prva se kategorija objašnjava kao »korištenje imaginativnog pristupa, kako bi se učenje učinilo interesantnijim i efektivnijim« (NACCCE, 1999, 89), što podrazumijeva nastavnika kao kreativnu ličnost koja posjeduje iskustvo i znanja o načinima provođenja kreativnih procesa. Novi pogledi na glazbeno obrazovanje počivaju i na primjeni konstruktivističke teorije, posebno u kontekstu razvoja glazbene kreativnosti kroz iskustvo improvizacije i komponiranja (Morfold, 2007; Webster, 2011; Wiggins, 1999; 2002; 2015). Scott $(2006,17)$ predlaže poticanje »kolaborativnog udruživanja « (eng. collaborative comunity) između nastavnika i učenika, kako bi se stvorilo uzajamno povjerenje, razmjena ideja i atmosfera koje potiču »dubinsko učenje« (eng. deep learning) kao jedno od osnovnih načela konstruktivizma.

Oblak $(1987,2000)$ je doprinijela značaju glazbene kreativnosti u slovenskoj glazbenoj pedagogiji postavljajući je kao jednu od tri temeljne glazbene aktivnosti, pored slušanja i izvođenja. Ona smatra da ove aktivnosti proizlaze iz prirode same glazbe koja se izražava kroz produkcije, reprodukcije i recepcije. Oblak dijeli glazbenu kreativnost na kreativnost u glazbi (kreiranje melodije, ritma, zvučnih slika, glazbenih improvizacija itd.) i kreativnost uz glazbu, kroz koju se doživljaj slušane glazbe izražava izvanglazbenim sredstvima (verbalno, likovno ili kroz pokret). Reprodukcija (slov. poustvarjalnost) je također uključena u oblike glazbene kreativnosti.

Iako u literaturi iz glazbene pedagogije na hrvatskom i srodnim jezicima nailazimo na dva pojma - kreativnost i stvaralaštvo - nije sasvim jasna diferencijacija u njihovom definiranju pa se u ovom radu smatraju sinonimima, što se može objasniti i činjenicom da se u opsežnoj literaturi na stranim jezicima koristi jedan pojam - kreativnost 
(eng. creativity, fr. créativité, njem. Kreativität). Pojam stvaralaštvo nalazimo i u Predmetnom programu Muzička kultura (2017) kojim je određena jedna od tri glazbene aktivnosti, uz izvođenje i slušanje, pa je pojam kao takav tretiran i u ovome radu.

Pedagoške strategije za podučavanje za kreativnost počivaju na razvijanju kreativnosti kod samih učenika, ali i razvijanju osobina koje čine kreativnu ličnost: radoznalosti, težnje ka inovativnim rješenjima, sposobnosti sagledavanja materijalnih i nematerijalnih pojava na neuobičajen način. Da bi se to postiglo, potrebno je naučiti učenike kako se uči, poticati njihovu motiviranost za učenje, stvoriti ambijent u kojemu se djeca osjećaju sigurnima za kreativno izražavanje.

\section{Kolaborativna kreativnost u glazbenom obrazovanju}

U teorijama o glazbenoj kreativnosti Burnard $(2016,12)$ gradi »komponentalni model kreativnosti« (eng. componential model of creativity) koji uključuje socijalno okruženje, motivirajuće zadatke, intrinzične/ekstrinzične nagrade te vještine relevantne za određenu domenu. U takvom kontekstu Burnard dijeli oblike kreativnosti na individualnu, empatičnu, kolaborativnu i interkulturalnu kreativnost te kreativnost koja se odvija putem suvremenih tehnologija, a u kojoj se potiče suradnja i interakcija kroz kolektivne kreativne procese u prostoru koji može biti i virtualan. Fischer i suradnici (2005, u: Bishop, 2018) objašnjavaju tri načina izražavanja kolaborativne kreativnosti: 1) serijski, ako individua kreira samostalno, a potom se u konačnom oblikovanju produkta nadograđuju ideje i rješenja drugih osoba; 2) paralelni, kada članovi grupe rade zadatak odvojeno, a zatim ga spajaju, dajući nešto novo; 3 ) simultani, ako članovi grupe zajedno i istovremeno stvaraju kreativni produkt. Paulus i Bown (2007) ističu značaj kolaborativne kreativnosti za razvoj kognitivno-socijalne motivacije, koja dovodi do kombinacija kognitivnih procesa u socijalnoj interakciji.

Kolaborativna kreativnost u glazbenoj se edukaciji, ali i u glazbenoj umjetnosti općenito, izražava na više područja i možemo reći da je njen integralni dio. Prva asocijacija za ovu tvrdnju su glazbeni ansambli. Rad u takvim ansamblima zahtijeva ne samo tijesnu suradnju, pronalaženje zajedničkog rješenja, nego i doživljaj glazbenoga djela, pa zato za glazbenike koji s vremenom stječu iskustvo zajedničkog sviranja kažemo da »zajedno dišu«, a ansambl postaje »jedno tijelo«. Osjećaj za 
muzičku cjelinu, kulminaciju, fraziranje, kroz uzajamno slušanje i dopunjavanje te izražavanje glazbenog doživljaja kroz pokret ili facijalnu ekspresiju, samo su neke osobine bez kojih se ne može zamisliti proces stvaranja i finalna izvedba djela pred publikom (Bishop, 2018). U žanrovima poput jazz glazbe, kolaborativna kreativnost je očigledna, jer se glazba stvara u određenom trenutku, a izvođači komuniciraju kroz improviziranje glazbenog materijala. U ovakvim procesima prisutno je i stanje zanesenosti (eng. state of flow) (Csikszentmihalyi, 1990) koje se danas istražuje ne samo kao stanje individue nego i kao stanje koje prati kolaborativnu kreativnost u procesima nastajanja glazbe (MacDonald, Byrne i Carlton, 2006).

Kolaborativna kreativnost je i stimulus za razvoj socijalnih vještina, otvorenosti za ideje drugih članova grupe, što doprinosi boljoj sinkroniziranosti i zajedničkoj težnji da ishod stvaralačkog procesa bude što kvalitetniji. Seddon i Biasutti (2009, u: Bishop, 2018) primjećuju tri razine interakcije tijekom opservacije komornog ansambla i jazz seksteta: instrukciju, kooperaciju i kolaborativnost koja se manifestira kao tijesna povezanost i interakcija u zajedničkom rješavanju problema. U kolaborativnoj kreativnosti glazbeni materijal postaje dijelom i sredstvom za postizanje izvanglazbenih ciljeva koji dominantno proizlaze iz socio-kulturološke matrice, što nikako ne znači da su procesi i njihovi ishodi lišeni glazbene kvalitete.

Webster (2018) skreće pažnju na značaj koji moramo dati kolaborativnoj kreativnosti u nastavi glazbe, povezujući različite umjetnosti, ali i neke naizgled udaljene discipline. On postavlja pitanje o tome dajemo li kao edukatori dovoljno znanja i vještina svojim studentima kako bismo ih osposobili za otvorenost na suradnju s drugima. U odgovoru Webster predlaže prisustvo nastavnika iz drugih umjetničkih predmeta na nastavi glazbe i obratno te uključivanje u projekte kako bi se granice i vidici proširivali i otvarale mogućnosti za nova metodička rješenja u glazbenoj edukaciji.

\section{Problem i ciljevi istraživanja}

Uvažavajući navedena svojstva kolaborativne kreativnosti i brojne mogućnosti koje nastava glazbe pruža u osnovnoj školi, provedeno je akcijsko istraživanje u kojemu se, kroz jasno osmišljene korake i metode učenja, nastojala unijeti promjena u nastavni proces s ciljem potica- 
nja glazbenog stvaralaštva u redovitoj nastavi glazbe u osnovnoj školi. Istraživanje je trajalo jednu školsku godinu, od listopada do početka lipnja školske godine 2017./2018., i bilo je podijeljeno u dva ciklusa.

Problem koji je bio identificiran odnosio se na nedovoljnu zastupljenost glazbenog stvaralaštva i didaktičkih preporuka za provođenje ove aktivnosti. Do tog se zaključka došlo na temelju analize Predmetnog programa Muzička kultura (2017) u kojemu je glazbeno stvaralaštvo zastupljeno kao aktivnost koja sadrži: izražavanje glazbenog doživljaja likovno, verbalno ili kroz pokret, kao i različite oblike stvaranja $u$ glazbi: osmišljavanje jednostavnih ritamskih i melodijskih improvizacija, oblikovanje ritamske pratnje, dopunjavanje započete melodije, stvaranje jednostavne melodijsko-ritamske cjeline na instrumentima Orffova instrumentarija. U programu se niti jedan krovni odgojno-obrazovni ishod ne odnosi na stvaralaštvo $u$ glazbi, za razliku od slušanja i izvođenja. Za provođenje glazbenog stvaralaštva u programu nisu predložene didaktičke preporuke, osim prijedloga da se stvaranje može kombinirati sa slušanjem i izvođenjem prilikom dostizanja ishoda učenja. Analizom je utvrđeno da je stvaralaštvo nedovoljno zastupljeno u udžbenicima i metodičkim priručnicima za Muzičku kulturu u osnovnim školama u Crnoj Gori. Nastavnica, koja je sudjelovala u istraživanju kao praktičar, bila je mišljenja da u svojoj praksi treba intenzivnije uključivati glazbeno stvaralaštvo.

Ciljevi koji su postavljeni na početku istraživanja odnosili su se na:

- Uvođenje promjene u nastavu glazbe kroz intenzivnije realiziranje glazbenog stvaralaštva kroz jasno osmišljene metodičke korake.

- Kreiranje integrativne nastave kao oblika poticanja glazbene kreativnosti.

- Ispitivanje na koji način učenici razvijaju socijalnu i glazbenu interakciju u kolaborativnoj kreativnosti.

- Ispitivanje poteškoća koje mogu, u školskim uvjetima, biti prepreka u realiziranju glazbene kreativnosti.

\subsection{Metodološki okvir istraživanja}

Za istraživanje smo primijenili kvalitativnu metodologiju akcijskog istraživanja u kojemu se na dinamičan način unapređuje pedagoška praksa i unosi promjena kroz planirane aktivnosti u realnim škol- 
skim uvjetima (Bognar, 2006; Mesec, 1994; Ševkušić, 2011). Akcijsko istraživanje se, kao vrsta kvalitativnog istraživanja, s posebnim intenzitetom primjenjuje u glazbenoj pedagogiji (Conway i Borst, 2001; Hartwing, 2014; Laprise, 2017; Rusinek, 2016), čime se ostvaruje stvarna povezanost istraživanja i prakse. Odjeljenje je, kao skupina učenika, u akcijskom istraživanju tretirano kao studija slučaja. U istraživanju je ostvarena povezanost istraživača i praktičara kroz dogovaranje, implementiranje metoda učenja te refleksivno promatranje i bilježenje onoga što se događalo tijekom nastavnih sati koji su bili obuhvaćeni istraživanjem.

\subsubsection{Sudionici}

Shodno prirodi kvalitativnih istraživanja, za uzorak je uzeta manja grupa sudionika. U istraživanju je sudjelovalo 30 učenika petog razreda $(\mathrm{N}=30)$, od čega 15 dječaka i 15 djevojčica, čija je prosječna starosna dob na početku istraživanja bila 10 godina. U istraživanju je, kao praktičar, sudjelovala njihova nastavnica glazbe, koja je u tom periodu imala 27 godina radnog iskustva u školi.

\subsubsection{Postupci i instrumenti za prikupljanje podataka}

U istraživanju su se prikupljali i dokumentirali svi podaci koji su pratili plan istraživanja. Jedan od postupaka bilo je sustavno promatranje i pisanje reflektivnog dnevnika od strane istraživača te prikupljanje dokumentacije u obliku video-snimki koje su sadržavale fragmente sa satova i snimke kreativnih produkata nastalih tijekom istraživanja. Nastavnica je vodila svoj dnevnik u kojemu je bilježila zapažanja, tijek aktivnosti i svoja razmišljanja. Učenici su pravili kratke zapise na kraju sata, dajući povratnu informaciju o provedenim aktivnostima. Dobiveni kvalitativni podaci su na kraju oba ciklusa kodirani i izvršena je njihova triangulacija.

\subsection{Tijek istraživanja}

Akcijsko istraživanje provedeno je u jednom odjeljenju petog razreda u jednoj osnovnoj školi u Crnoj Gori. ${ }^{2}$ Istraživanje se odvijalo u sudionika.

${ }^{2}$ Naziv škole nije naveden kako bi se zadovoljili etički standardi o zaštiti identiteta 
sklopu redovite nastave predmeta Muzička kultura u školama u Crnoj Gori, zastupljenog s po jednim satom tjedno (Predmetni program Muzička kultura, 2017) tijekom školske godine 2017./2018. Istraživanje se realiziralo u dva ciklusa, određena prema školskim polugodištima. Kreiran je godišnji plan rada prema programom predviđenim odgojnoobrazovnim ishodima i ishodima učenja (Predmetni program Muzička kultura, 2017) u kojem je kroz planirane aktivnosti poticano glazbeno stvaralaštvo. Od ukupnog godišnjeg broja sati (35), glazbeno stvaralaštvo je kao središnja aktivnost realizirano kroz 8 sati u prvom i 8 sati u drugom ciklusu. Uloga istraživača je bila u tome da osmisli pripreme za navedene sate, odabere metode rada i sadržaje prema kojima će nastavnica realizirati nastavu.

Naglasak je stavljen na nekoliko cjelina kojima je bila obuhvaćena korelacija među predmetima, ali i na pripremu i realiziranje integrativne nastave kroz pronalaženje mogućih zajedničkih tema među različitim predmetima kroz njihovu integraciju (Rassell-Bowie, 2009, u: Murphy, 2017). Time je ostvarena kolaborativna kreativnost među nastavnicima koji su bili otvoreni za suradnju. Na taj smo način kreirali jedan broj blok-sati u trajanju od 90 minuta, što je procijenjeno kao optimalan vremenski okvir za realiziranje predviđenih aktivnosti. Struktura navedenih 8 nastavnih sati bila je takva da se u prvom ciklusu kolaborativna kreativnost provodila kroz 6 sati, od kojih su dva sata realizirana kao blok-sat u sklopu integrativne nastave s predmetom Crnogorski, srpski, bosanski i hrvatski (CSBH) jezik i književnost. Preostala dva sata realizirana su kao blok-sat Muzičke kulture na kojemu je ostvarena korelacija s Likovnom kulturom, a učenici su u individualnom obliku rada likovno izražavali muzički doživljaj kompozicije Capriccio br. 24 N. Paganinija. Blok-sat Muzičke kulture realiziran je u obradi nastavne jedinice Upoznajmo malog Mozarta.

Kreirane aktivnosti većinom su realizirane kroz oblik simultane kolaborativne kreativnosti (Fischer i sur. 2005, u: Bishop, 2018). U prvom ciklusu pozornost istraživača bila je usmjerena na stvaralačke procese učenika, bez procjene stvaralačkog produkta, što odgovara »mini c « kreativnosti (Kaufman i Beghetto, 2009). Nakon provedenog prvog ciklusa i analize dobivenih podataka procijenjeno je da bi se u drugom ciklusu učenici mogli usmjeravati ka kreativnom produktu, imajući u vidu da su postupno razvijali određene glazbene vještine, poput sviranja na ritamskim i melodijskim instrumentima Orffova instrumentarija, 
uočavanja glazbenih karakteristika (tempa i dinamike) i vještinu usklađenog izvođenja svojih kreativnih produkata.

Drugi ciklus istraživanja odvijao se tijekom drugog polugodišta, od veljače do kraja svibnja 2018. godine. Kvaliteti stvaralačkog produkta i sami učenici su pridavali značaj kroz potrebu objašnjavanja načina na koji su realizirali provedene aktivnosti. Povratne informacije koje nastavnik dobiva umnogome pomažu u ostvarenju kolaborativne suradnje s učenicima i stjecanju boljeg uvida u njihove potrebe i mogućnosti. Istraživanja su pokazala da su djeca ovog uzrasta sposobna generirati glazbeni materijal u smislene cjeline te se više usmjeriti prema krajnjem ishodu stvaralačkog procesa (Kratus, 1989). Nastup na školskom glazbenom natjecanju omogućio im je da javno prikažu svoje kreativne produkte. Selekcija sadržaja ujedno je potakla kritičko mišljenje koje su izrazili kroz komentare o tome što bi u točki mogli promijeniti. U drugom je ciklusu integrativna nastava provedena s predmetom Informatika, kao blok-sat, gdje su učenici kreativne procese provodili kroz rad u paru. Integracija je ostvarena kroz temu upoznavanja s programom Finale u kojemu su učenici kreirali svoju melodiju. Integracija je ostvarena i s predmetom Likovna kultura kroz upoznavanje s drvenim puhačkim instrumentima te s osnovnim i izvedenim bojama (nastavna jedinica Čujem boju, vidim zvuk). Učenici su u individualnom obliku rada izražavali glazbeni doživljaj koristeći likovna sredstva.

Nakon provedenog drugog ciklusa uslijedilo je kodiranje prikupljenih podataka, njihovo kategoriziranje (socijalna interakcija, glazbena interakcija, integrativna nastava, poteškoće). Uspoređeni su analizirani podaci iz oba ciklusa i izvršena je njihova triangulacija.

\subsubsection{Aktivnosti vezane za kolaborativnu kreativnost \\ u prvom ciklusu istraživanja}

Prvi ciklus istraživanja bio je usmjeren na kreativni proces, s obzirom da su se učenici prvi puta susreli s ovim oblikom rada. Aktivnosti su postupno uvođene, od upotrebe tijela kao izvora zvuka, stvaranja jednostavne ritamske pratnje na instrumentima Orffova instrumentarija, stvaranja zvučnih slika, do uvođenja sviranja na blok-flauti i kreiranja jednostavnih aranžmana. U Tablici 1 predstavljene su nastavne jedinice u kojima je poticana kolaborativna kreativnost. 
Tablica 1. Pregled nastavnih jedinica u kojima je realizirana kolaborativna kreativnost s kratkim opisom aktivnosti i sredstava koja su korištena u prvom ciklusu istraživanja.

\begin{tabular}{|c|c|c|}
\hline Naziv nastavne jedinice & Aktivnosti & $\begin{array}{c}\text { Sredstva koja se koriste u } \\
\text { realizaciji kreativnog zadatka }\end{array}$ \\
\hline $\begin{array}{l}\text { Učimo nove notne vrijed- } \\
\text { nosti (jedan nastavni sat) }\end{array}$ & $\begin{array}{l}\text { U grupama osmišljavaju pokre- } \\
\text { te uz koje prate ritam. Osmišlja- } \\
\text { vaju ritamsku pratnju za nauče- } \\
\text { nu pjesmu. }\end{array}$ & $\begin{array}{l}\text { Tijelo kao izvor zvuka, pokret, } \\
\text { glas. }\end{array}$ \\
\hline $\begin{array}{l}\text { Muzika nas vodi kroz Crnu } \\
\text { Goru (jedan nastavni sat) }\end{array}$ & $\begin{array}{l}\text { U grupama osmišljavaju ritam- } \\
\text { sku pratnju i koreografiju za } \\
\text { dvije narodne pjesme iz Crne } \\
\text { Gore. }\end{array}$ & $\begin{array}{l}\text { Instrumenti s neodređenom visi- } \\
\text { nom tona (zvečke, triangl, daire, } \\
\text { kastanjete). }\end{array}$ \\
\hline $\begin{array}{l}\text { Doći ću iz šume čak (blok- } \\
\text { sat), integrativna nastava s } \\
\text { CSBH jezikom i književ- } \\
\text { nošću }\end{array}$ & $\begin{array}{l}\text { Slušaju kompozicije kojima su } \\
\text { glazbom predstavljene životinje } \\
\text { i verbalno izražavaju dojmove. } \\
\text { Analiziraju pjesme iz zbirke } \\
\text { poezije na koje se odnosi slu- } \\
\text { šana muzika. U grupama osmi- } \\
\text { šljavaju zvučne slike za četiri } \\
\text { pjesme iz zbirke. }\end{array}$ & $\begin{array}{l}\text { Instrumenti s određenom i ne- } \\
\text { određenom visinom tona, glas, } \\
\text { dva lista papira. }\end{array}$ \\
\hline $\begin{array}{l}\text { Upoznajmo malog Mozarta } \\
\text { (blok-sat) }\end{array}$ & $\begin{array}{l}\text { U grupama izvode melodiju i } \\
\text { osmišljavaju melodijsku i ri- } \\
\text { tamsku pratnju. }\end{array}$ & $\begin{array}{l}\text { Orffov instrumentarij (blok fla- } \\
\text { ute, udaraljke s određenom i ne- } \\
\text { određenom visinom tona). }\end{array}$ \\
\hline
\end{tabular}

S obzirom na to da je potrebno napraviti godišnji plan na početku školske godine, u dogovoru s upravom škole omogućeno je da, sukladno potrebama, taj plan bude fleksibilan. Pokazalo se da su i sami učenici tijekom prvog ciklusa bili više usmjereni na stvaralački proces. U svom dnevniku nastavnica je zapisala sljedeća zapažanja s prvog sata:

»Podjelom na grupe po notnim trajanjima učenici su imali zadatak da pokretom predstave 'svoju' notnu vrijednost. Morali su se uskladiti i dogovoriti na razini grupe. Povremeno smo ih usmjeravali, isprobavajući različite kombinacije pokreta. Rad u grupi potiče njihovu međusobnu suradnju. Učenici koji nisu ranije usvojili znanja o notnim trajanjima su ih, u suradnji s ostalima u grupi, savladali.« (Dnevnik nastavnice, nastavna jedinica Učimo nove notne vrijednosti, 6. 10. 2017.)

Veći broj grupa formiran je na satu u okviru kojega je realizirana nastavna jedinica Muzika nas vodi kroz Crnu Goru (25. 10. 2017.). Grupe su imale više različitih zadataka: dvije grupe svirale su melodije narodnih pjesama na blok-flauti, dvije su osmišljavale ritamsku pratnju, a dvije koreografiju. Na kraju su se grupe objedinile sa zadatkom 
da izvedu naučene pjesme uz koreografiju i pratnju na ritamskim instrumentima. Na početku rada na zadatku primijećeno je da se stvara veliki žamor i da djeca burno raspravljaju o tome što izvesti i na koji način. Ova faza traje kratko jer su učenici svjesni da se na razini grupe moraju dogovoriti, što se čini kao višestruko korisna prilika za razvijanje socijalnih vještina i tolerancije prema ostalim članovima koji različito razmišljaju. U reflektivnom dnevniku zabilježeno je sljedeće zapažanje:

»Na početku je jedna učenica, koja ide na satove plesa, predlagala pokrete, a drugi učenici su u početku negodovali s izjavama poput: 'Praviš se važna, želiš biti glavna' itd. Međutim, sama činjenica da će predstaviti pred drugima svoj rad motivirala ih je da se brzo solidariziraju i ujedine pa su uglavnom prihvatili sugestije.« (Reflektivni dnevnik, nastavna jedinica Glazba nas vodi kroz Crnu Goru, 25. 10. 2017.)

Nastavna jedinica Doći ću iz šume čak (13. 11. 2017.) realizirana je kroz integrativnu nastavu sa CSBH jezikom i književnošću. Zadatak koji su imali sastojao se u tome da na osnovu pjesama iz zbirke poezije za djecu Doći ću iz šume čak (Martinović-Bogojević, 2015) u kojima su opisane različite životinje osmisle zvučne slike za odabrane pjesme koristeći udaraljke Orffova instrumentarija s neodređenom i određenom visinom tona. Zbirka pjesama je multimedijalna, s pratećim skladbama u kojima je skladateljica Nina Perović osmislila glazbene portrete životinja. Učenici su u prvom dijelu slušali četiri kompozicije i tehnikom »oluje ideja « izlagali svoja zapažanja. Primijenili su znanja o glazbenim pojavama, tempu i dinamici, koristeći glazbene izraze. Kroz ovaj način aktivnog slušanja poticano je »kreativno slušanje « (Kratus, 2017) kojeg čine konvergentno slušanje (prepoznavanje glazbenih karakteristika) i divergentno slušanje (izražavanje glazbenog doživljaja). Nakon toga je uslijedila analiza pjesama s nastavnicom CSBH jezika i književnosti. Prilikom stvaranja zvučnih slika učenici su se dogovarali o raspodjeli instrumenata na razini grupe. Primijećeno je da su imali kratke rasprave, poput onih da je netko među njima htio određeni instrument, ali da ga je drugi član grupe prvi izabrao. U reflektivnom dnevniku je zabilježeno:

»Primjećujem da na ovaj način razvijaju toleranciju. Djevojčice popuste prve. Zamijene se za instrument da se ne bi raspravljale. Morali smo im dati neke instrukcije o tome da je potrebno da se na razini grupe dogovore što će osmisliti i da stave na papir raspored kad se tko i na koji način uključuje. Sugerirano im je da izaberu člana grupe koji će koordinirati rad grupe. Moj dojam je 
bio da nećemo dobiti nikakve kreativne produkte. Učenici su bili veoma bučni, euforični. Imali su na raspolaganju svega 15 minuta za stvaranje zvučnih slika. Kada je svaka grupa demonstrirala što je osmislila, bila sam iznenađena dobivenim rezultatima.« (Reflektivni dnevnik, nastavna jedinica Doći ću iz šume čak, 13. 11. 2017.)

Na kraju prvog ciklusa učenici su dali povratne informacije o ukupnim dojmovima i idejama za sljedeći ciklus. Na pitanje vole li više rad u grupi ili individualni rad, od 23 učenika, njih 20 (87 \%) odgovorilo je da više voli rad u grupi. Iznosimo neka od obrazloženja:

»Tada se svi zajedno družimo, smijemo, veselimo i učimo nešto o muzici; Zato što se volimo dogovarati kako ćemo to odsvirati i volimo imati više instrumenata, jer kada sam sama imam samo jedan; Zato što se družim s drugarima i zabavljam s njima; Zato što je lakše kad radim u grupi; Zato što volim kad se dijelimo u grupe jer onda naučimo nešto novo i zajedno sudjelujemo u radu; Kad nas je više, imamo više ideja; Zato što, po mom mišljenju, bolje ispadne ono što stvaramo; Volim, jer svatko tada kaže svoje mišljenje i onda budemo najbolji, zato što možemo učiti jedni od drugih i lakše mi je.«(Odgovori učenika, 26. 12. 2017.)

Oni koji više vole individualni rad dali su sljedeća obrazloženja:

»Zato što neki misle da su najbolji i da su glavni; Zato što kad sviram u grupi, ne mogu čuti kako ja sviram; Zato što volim stvarati sam.« (Odgovori učenika, 26. 12. 2017.)

Iz ovih odgovora primjećujemo da su učenici isticali upravo značaj suradnje, zadovoljstvo u zajedničkom radu te više ideja koje imaju tijekom zajedničkog stvaranja.

\subsubsection{Analiza i interpretacija podataka na kraju prvog ciklusa}

Analizirajući rezultate prvog ciklusa moglo se uvidjeti da jedan školski sat u trajanju od 45 minuta ne pruža dovoljno vremena za provedbu svih faza kreativnog procesa. Tu se misli na generiranje i eksploraciju ideja, organiziranje ideja, selekciju, reviziju, transformaciju, modifikaciju ideja i finalno izvođenje (Rusinek, 2016). Malo ili gotovo nimalo vremena ostaje za evaluaciju postignutih rezultata. Nastavne jedinice osmišljene u okviru dva povezana školska sata omogućile su provođenje i ove faze, u čemu su učenici aktivno sudjelovali, pokazujući zadovoljstvo u izražavanju svoga mišljenja. 
Integrativna nastava učenicima je pružila novi oblik učenja, povezivanje tema iz različitih područja kroz analizu poezije i aktivno slušanje kompozicija koje su inspirirane poetskim tekstovima. Kompozicije i poezija pokazale su se kao efikasan kreativni poticaj za kreiranje zvučnih slika. Analizom video-snimki primjećuje se smislena upotreba glazbenih instrumenata, organiziranost u nastupu pojedinih članova grupe i logična zaokruženost zvučnih slika.

Pri kraju ciklusa primijećeno je da djeca daju značaj kreativnom produktu, što stvara snažnu intrinzičnu motivaciju (Amabile, 1996) unutar grupe. Želja da prikažu drugima svoj zadatak stvara bolju interakciju i podjelu odgovornosti. Budući da su učenici izrazili zadovoljstvo zajedničkim radom, odlučili smo u drugom ciklusu više naglasiti sintezu njihovih znanja i vještina i više se usmjeriti na stvaralački produkt. Grupe smo uvijek formirali spontano tako da je njihov sastav bio različit što je doprinijelo boljoj interakciji učenika. Nije primijećeno da je bilo tko od učenika negodovao zbog grupe kojoj pripada niti da je grupa diskriminirala bilo kojeg od svojih članova. Povremene nesuglasice pokazale su da učenici doživljavaju grupu kao cjelinu te da ne prihvaćaju kada jedan od članova želi dominirati. Jedine poteškoće bile su vezane uz praćenje grupe od same nastavnice, jer je brojnost učenika u razredu velika, tako da je prisustvo istraživača, koji se povremeno uključivao u nadgledanje grupa, umnogome pomoglo da se raspodijele aktivnosti i ostvari kvalitetnija suradnja s učenicima.

\subsubsection{Aktivnosti vezane za kolaborativnu kreativnost u drugom ciklusu istraživanja}

Drugi ciklus akcijskog istraživanja trajao je od veljače do kraja svibnja 2018. godine. Tijekom drugog ciklusa u školi je organizirano školsko natjecanje »Biramo najraspjevaniju razrednu zajednicu«. U ožujku je napravljen zajednički dogovor oko nastupa na natjecanju s točkom u kojoj će se iskoristiti neki od ishoda kolaborativnog kreativnog procesa (melodije na blok-flauti, zvučne slike). Prednost akcijskog istraživanja ogleda se i u promjenama prethodno osmišljenih koraka, koje nastaju spontano i neočekivano pa se govori o višedimenzionalnoj spirali, što upućuje na »značaj spontanosti u stvaralačkom i razvojnom procesu akcijskog istraživanja« (Bognar, 2006, 182). 
Tablica 2. Pregled nastavnih jedinica u kojima je realizirana kolaborativna kreativnost s prikazom aktivnosti i korištenih sredstava u drugom ciklusu

\begin{tabular}{|l|l|l|}
\hline \multicolumn{1}{|c|}{ Nastavna jedinica } & \multicolumn{1}{|c|}{ Aktivnosti } & \multicolumn{1}{|c|}{$\begin{array}{l}\text { Sredstva koja se koriste za } \\
\text { realizaciju kreativnog zadatka }\end{array}$} \\
\hline Moja melodija (jedan sat) & $\begin{array}{l}\text { U grupama osmišljavaju i do- } \\
\text { punjavaju muzičku frazu. }\end{array}$ & Blok flaute, list bloka, olovka. \\
\hline $\begin{array}{l}\text { Priprema igrokaza Soko (1 } \\
\text { sat) }\end{array}$ & $\begin{array}{l}\text { Na razini odjeljenja osmišlja- } \\
\text { vaju točku (grupni rad). }\end{array}$ & $\begin{array}{l}\text { Ritmički i melodijski instrumen- } \\
\text { ti, CD, tiskani tekst pjesme Soko }\end{array}$ \\
\hline $\begin{array}{l}\text { Priprema koreografije Moja } \\
\text { Crna Gora (dio igrokaza) } \\
\text { (1 sat) }\end{array}$ & $\begin{array}{l}\text { Na razini odjeljenja osmišlja- } \\
\text { vaju koreografiju (grupni rad). }\end{array}$ & CD \\
\hline $\begin{array}{l}\text { Proljeće - osmišljavam me- } \\
\text { lodiju (jedan sat) }\end{array}$ & $\begin{array}{l}\text { Osmišljavanje melodije na za- } \\
\text { dani tekst (rad u paru). }\end{array}$ & $\begin{array}{l}\text { Literarni tekst na koji pjevanjem } \\
\text { osmišljavaju melodiju. }\end{array}$ \\
\hline $\begin{array}{l}\text { Kompjuter mi pomaže da } \\
\text { stvaram(blok-sat;integrativ- } \\
\text { na nastava glazbe i informa- } \\
\text { tike) }\end{array}$ & $\begin{array}{l}\text { Upoznaju se s FINALE pro- } \\
\text { gramom. U paru istražuju pro- } \\
\text { gram i nastoje kreirati svoje } \\
\text { melodije (rad u paru). }\end{array}$ & $\begin{array}{l}\text { Kompjuteri s instaliranom demo- } \\
\text { verzijom FINALE programa. }\end{array}$ \\
\hline
\end{tabular}

Dinamika uvođenja kolaborativne kreativnosti bila je intenzivnija u drugom ciklusu. Pripreme igrokaza za školsko natjecanje odvijale su se i u okviru dodatne nastave. Iako natjecanje potiče ekstrinzičnu motivaciju, ovo iskustvo je pokazalo da ona nije inhibirala kreativnost, naprotiv. Stoga se ovdje može govoriti o sinergističnoj ekstrinzičnoj motivaciji (eng. synergistic entrinzic motivation) koja je kompatibilna s intrinzičnom motivacijom (Collins i Amabile, 1999), kada vanjski motivatori pozitivno utječu na unutrašnje. O tijeku pripreme točke za nastup, nastavnica je zapisala:

»Djeca su davala prijedloge i dogovorili smo se da cijela točka ima formu ABA s tim da središnji dio bude pjesma Soko koju recitiraju s glazbenom podlogom koju sami osmisle. Takvo iskustvo imali su na jednom od prethodnih sati tako da im je bilo jasno kako sve osmisliti. Nastojali smo uvažiti njihove prijedloge i pokušati da sami dođu do konačnih rješenja. Onda smo, da bismo zadovoljili zahtjeve natjecanja da mora biti i dio s pjevanjem, uključili pjesmu Moja Crna Gora. Rodila se ideja da se uz pjesmu osmisli i koreografija, tako da je na sceni bio pravi igrokaz gdje su zaista imali dojam da su sve sami osmislili (...) Imali su osjećaj da je ono što rade vrijedno da se javno prikaže i da se ne trebaju sramiti onoga što stvaraju.« (Dnevnik nastavnice, 20. 4. 2018.)

Tema sata Moja melodija odgovarala je ishodima učenja: učenici sviraju na blok-flauti, usavršavaju tehniku; sviraju koristeći notno pi- 
smo; aktivno sudjeluju u grupnom sviranju; vrednuju svoje izvođenje i izvođenje grupe; razumiju i znaju objasniti odnos notnih trajanja i koriste nova notna trajanja (Predmetni program Muzička kultura, 2017). Zadatak je bio da učenici u grupama osmisle nastavak započete melodije, koristeći blok-flaute. Za rad su imali na raspolaganju 20 minuta. Kako učenici osnovne škole nemaju jasnu predodžbu o tonskim visinama, pisali su note, popunjavali taktove pa isprobavali kako to zvuči i zatim korigirali ono što im se ne sviđa. Time se u grupi razvija kritičko mišljenje, sposobnost rješavanja problema na različite načine i divergentno mišljenje. Na kraju sata izvedeno je pet muzičkih fraza na blokflauti uz harmonijsku pratnju nastavnice na klaviru. Ostalo je dovoljno vremena za evaluaciju pa su učenici komentirali svoje kompozicije i kompozicije ostalih grupa, pohvaljujući jedni druge i pozdravljajući melodiju svake grupe aplauzom. Dvije melodije kasnije su izabrane za točku koju su pripremali za školsko natjecanje.

Posljednji sat u okviru istraživanja, na kojem je primijenjena kolaborativnost kroz rad u paru, bio je sat integrativne nastave Muzičke kulture i Informatike. Nastavnik informatike bio je otvoren za suradnju i sam se upoznajući s programom FINALE, koji je prethodno instalirao na svim kompjuterima u svom kabinetu. Iako smo imali nekih tehničkih poteškoća jer se na nekim kompjuterima nije moglo čuti ono što su učenici zapisali što je kod nekih očekivano izazvalo razočarenje, novi ambijent i upotreba suvremenih tehnologija im je bila bliska i poticajna. U novonastaloj situaciji nastojali su pomoći jedni drugima kako bi se sve »kompozicije « mogle čuti. U svojim zabilješkama zapisali su neke od sljedećih dojmova (Dojmovi učenika, 16. 5. 2018.):

»Ja volim satove glazbe, ali mi se ovaj pogotovo svidio. Zato što je bio s kompjuterom, a i volim da kuckam po kompjuterima. Ja sam radila s mojim najboljim prijateljicama. Odslušali smo našu kompoziciju i mnogo mi se svidjela. Voljela bih da još jednom najzanimljiviji sat provedemo zapisujući note u programu FINALE.«(U2)

»Bilo mi je lijepo stvarati glazbu. Pomogla mi je moja prijateljica U12, jer ona zna dobro note.« (U27)

»Ovaj sat je bio divan! Sve je bilo zabavno, iako nam U 23 ništa nije predlagao, čak i malo smetao (...) Slušali smo prelijepe kompozicije naših prijatelja. Važno je da smo naučili da radimo zajedno u veselju.« (U30)

»Na posljednjem satu bilo mi je super. Nije bilo teško niti dosadno. Moja prijateljica i ja smo uživale dok smo komponirale. Kada smo pustili da čujemo, 
bilo je očaravajuće. Bile smo ponosne na sebe i pomogle drugima da sačuvaju kompozicije. Kada porastem, htjela bih biti prava kompozitorica.«(U12)

\subsubsection{Analiza i interpretacija podataka}

na kraju drugog ciklusa

Postignuća koja su učenici ostvarili kroz aktivnosti kolaborativne kreativnosti tijekom drugog ciklusa istraživanja odrazila su se na povezanost učenika i ostvarivanje intenzivne interakcije ne samo među djecom nego i povezanosti nastavnice s njima. To se moglo zaključiti na temelju analize kvalitativnih podataka, gdje je nastavnica izrazila da se s učenicima ovog razreda zbližila više nego s učenicima iz ostalih razreda s kojima nije provodila stvaralačke aktivnosti. Učenici su iskazali ne samo da vole surađivati nego i da vole učiti jedni od drugih. Izražavanje individualnosti ogledalo se u angažiranju onih koji su neke vještine bolje savladali, poput sviranja ili plesa, a čije su sugestije i pomoć drugi rado prihvaćali. Primijećeno je da se introvertniji učenici lakše oslobađaju srama kada stvaraju u grupi i da su s vremenom postali aktivniji.

Veća usmjerenost na produkt je kod ovog uzrasta bila i očekivana pa smo drugi ciklus podredili generiranju njihovih ideja. Kada je Kratus (1989) istraživao procese komponiranja kod djece uzrasta od 6 do 11 godina mjereći vrijeme koje posvećuju zadatku, uvidio je da starija djeca stvaraju glazbu slično odraslim kompozitorima, kratko se zadržavaju na istraživanju materijala i počinju intenzivno raditi na proizvodnji produkta. Njihova usmjerenost na krajnji rezultat bila je očigledna i u ovom istraživanju. Učenike koji su imali zadršku u prvom ciklusu, kao što je učenik U6 koji je u zabilješkama zapisivao da mu smeta buka u razredu, da ne može čuti svoje sviranje, da su svi loše pjevali, a koji pohađa muzičku školu, nastojali smo uključiti tako što im je dano na važnosti pa smo ovog učenika angažirali da predstavi gitaru i odsvira solo kompoziciju u nastavnoj jedinici posvećenoj trzalačkim žičanim instrumentima. Na kraju istraživanja on je zapisao: »Naučio sam nove pjesme i shvatio sam da nas je svo ovo vrijeme učiteljica učila prijateljstvu.«

\section{Zaključak}

Iako su naša očekivanja na početku akcijskog istraživanja odgovarala kasnije dobivenim rezultatima na polju kolaborativnosti, istraživanje je potvrdilo da je učenicima ovoga uzrasta važan kako proces, 
tako i produkt kojim generiraju svoje glazbene ideje (Kratus, 1989). Kroz kolaborativnu kreativnost razvijaju osjećaj za timski rad i postaju otvoreniji za ideje drugih. U njihovim izjavama zapažamo da im je rad u grupi zabavniji i da se tako više druže, što odgovara i sigurnom okruženju, neophodnom za razvoj kreativnosti. Miell i MacDonald (2000) u svom istraživanju zapažaju da unaprijed izgrađeno prijateljstvo značajno utječe na proces i kvalitetu produkata jer je suradnja bazirana na zajedničkim interesima, razumijevanju i povjerenju. Socijalna interakcija učenika bila je bolje ostvarena u drugom ciklusu jer se nisu događali nesporazumi koji su se sporadično javljali u prvom ciklusu kada su članovi grupe nerado prihvaćali ideje onih koji »žele biti glavni $\ll$.

Prilikom analize podataka ustanovljeno je da se uloga nastavnika u vođenju kolaborativne kreativnosti treba odvijati na način da on bude facilitator u ostvarivanju glazbene interakcije, što sugerira i Wiggins (1999), ali i moderator u slučaju da se pojavi neslaganje unutar same grupe. Kako su učenici u drugom ciklusu bili usmjereni ka kreativnom produktu, nastavnik treba biti i objektivni ohrabrivač, pohvaljujući učenike, ali istovremeno ukazujući i na glazbene komponente koje bi u budućim procesima mogle poboljšati kvalitetu produkta.

Učenici su na području glazbene interakcije isticali da im je proces lakši kada stvaraju zajedno, da imaju više ideja i više glazbenih instrumenata kojima raspolažu, što se pozitivno odrazilo na produktivnost kreativnog procesa.

Integrativna nastava pružila je učenicima novi oblik učenja i povezivanje znanja iz različitih područja, što doprinosi i konstruktivističkom načinu učenja (Scott, 2006; Wiggins, 1999; 2002; Webster, 2011). Promjena ambijenta (kabinet informatike), prisustvo dva nastavnika i optimalno vrijeme za realiziranje aktivnosti poticali su motiviranost za rad. Integrativna nastava pokazala se poticajnom i za same nastavnike koji su bili otvoreni za suradnju i koji su u ovom istraživanju po prvi puta realizirali ovaj oblik nastave. Crnogorski programi djelomično su otvoreni pa nastavnici mogu organizirati do $20 \%$ od ukupnog godišnjeg broja sati prema svom slobodnom izboru što otvara mogućnost da se i izvan programom predviđenih tema može slobodnije kreirati integracija. U ovom istraživanu to je bio slučaj s upoznavanjem kompjuterskog programa FINALE i obradom multimedijalne zbirke Doći ću iz šume čak (Martinović-Bogojević, 2015). 
Kroz naknadnu analizu video-materijala zaključeno je da više grupa u jednom prostoru, njihovo eksperimentiranje sa zvukom i glasne rasprave ne ostavljaju dojam koji bi doprinio estetskom odgajanju što može odvratiti nastavnike od provođenja aktivnosti glazbenog stvaralaštva. Kompetencije nastavnika o fazama kreativnih procesa kod djece neophodne su kako bi se stvaralaštvo moglo uspješno izraziti, što podrazumijeva i toleranciju prema fazi eksploracije i uključivanje u rad grupa kroz davanje osnovnih smjernica kako bi se proces uspješnije realizirao.

Otežavajuća okolnost bio je i nedovoljan broj sati Muzičke kulture koji je posljednjom reformom osnovnog obrazovanja u Crnoj Gori, provedenom 2016. godine, u četvrtom i petom razredu umanjen za $50 \%$. Trajanje školskog sata od 45 minuta jedna je od poteškoća za realiziranje svih faza kreativnog procesa, što je u istraživanju nadvladano organiziranjem blok-sati. Budući da peti razred u crnogorskim školama predstavlja prelazak s razredne na predmetnu nastavu, godišnji raspored sati bio je fleksibilniji pa je bilo moguće provoditi manje izmjene. Velik broj učenika u odjeljenju može biti još jedna otežavajuća okolnost za poticanje glazbene kreativnosti pa se kolaborativna kreativnost pokazala kao oblik rada koji uključuje sve učenike i omogućuje postupno razvijanje socijalne i glazbene interakcije. Postupna usmjerenost učenika s procesa na produkt pokazala je praktičnu primjenu stečenih glazbenih znanja u stvaralačkim aktivnostima, što Wiggins (2002) naziva »smislenim glazbenim razmišljanjem« (eng. meaningful music thinking).

Dobrobit ovog istraživanja bila je i promjena nastavne prakse nastavnice koja je sudjelovala u istraživanju te njeno dalje primjenjivanje metoda i aktivnosti. Na taj je način postignuta i emancipacijska uloga koju akcijska istraživanja imaju (Ševkušić, 2011). Iako u ovome radu nije bilo moguće prikazati sve aspekte istraživanja, kolaborativna kreativnost u glazbi, kroz predstavljene primjere, može biti poticajna za glazbene pedagoge koji svoj rad s djecom vide kao dinamičan, kreativan, inspirativan i nadasve suradnički proces. Da su djeca uvijek otvorena za promjene koje im pričinjavaju zadovoljstvo, ilustrira i izjava učenice na kraju istraživanja: »Važno je da smo naučili raditi zajedno u veselju!« 


\section{Literatura}

Amabile, Teresa (1996), Creativity in Context, New York: Avalon Publishing.

Bishop, Laura (2018), »Collaborative musical creativity: How ensambles coordinate spontaneity «, Frontiers in Psychology, doi: https://doi.org/10.3389/fpsyg.2018.01285

Bognar, Branko (2006), »Akcijska istraživanja u školi«, Odgojne znanosti, Vol. 8, No. 1(11), Osijek: Filozofski fakultet, str. 177-190.

Burnard, Pamela (2016), »Rethinking 'musical creativity' and the notion of multiple creativities in music «, u: Odena, Oscar (ur.), Musical Creativity: Insights from Music Education Research, 2nd Edition, London and New Yotk: Routledge, Taylor \& Francis Group, str. 5-29.

Collins, Mary Ann i Amabile, Teresa M. (1999), »Motivation and creativity«, Sternberg, Robert (ur.), Handbook of Creativity, Cambridge University Press, str. 297-313. doi: https://doi.org/10.1017/CBO9780511807916.017

Conway, Colleen, M. i Borst, James (2001), »Action research in music education«, Update: Applications of Research in Music Education, 19/2, str. 3-8. doi: https://doi.org/10.1177\%2F87551233010190020102

Csikszentmihalyi, Mihaly (1990), Flow: The Psychology of Optimal Experience, New York: Harper \& Row.

Glăveanu, Vlad Petre (2010), »Paradigms in the study of creativity: Introducing the perspective of cultural psychology «, New Ideas in Psychology, 28(1), str. 79-93. doi: https://doi.org/10.1016/j.newideapsych.2009.07.007

Guilford, Joy Paul (1950), »Creativity«, American Psychologist, 5/9, str. 444-454. doi: https://doi.org/10.1037/h0063487

Hartwig, Key Ann (2014), Research Methodologies in Music Education, Newcastle upon Tyne, UK: Cambridge Scholars Publishing.

Kaufman, James, C. i Beghetto, Ronald, A. (2009), »Beyond big and little: The four C model of creativity «, Review of General Psychology, 13(1), str. 1-12. doi: https://doi.org/10.1037/a0013688

Kratus, John (1989), »A time analysis of the compositional process used by children ages 7 to 11 «, Journal of Research in MusicEducation, 37(1), str. 5-20. doi: https://doi.org/10.2307/3344949

Kratus, John (2017), »Music listening is creative«, Music Educators Journal, 103(3), str. 46-51. doi: https://doi.org/10.1177/0027432116686843

Laprise, Richard (2017), »Empowering the music educator through action research «, Music Educators Journal, 104(1), 2, str. 8-33.

doi: https://doi.org/10.1177/0027432117708012 
Lin, Yu-Sien (2011), »Fostering creativity through education: Conceptual framework of creative pedagogy «, Creative Education, Vol. 2, No. 3, str. 149-155. doi: https://doi.org/10.4236/ce.2011.23021

MacDonald, Rymond; Byrne, Charles i Carlton, Lana (2006), »Creativity and flow in musical composition: An empirical investigation «, Psychology of Music, 34(3), str. 292-306. doi: https://doi.org/10.1177/0305735606064838

Martinović-Bogojević, Jelena (2015), Doći ću iz šume čak, Podgorica: ZUNS.

Martinović-Bogojević, Jelena i Papić, Milena (2016), S muzikom rastem, Udžbenički komplet za 5. razred, Podgorica: ZUNS.

Mesec, Blaž (1994), Kvalitativna metodologija. Akcijsko in evalvacijsko raziskovanje, arhiv dr. Blaža Meseca. Dostupno na: https://sites.google.com/site/ kvalitativnametodologija/metodologija-ii/skripta-ii [1. 10. 2017.]

Miell, Dorothy i MacDonald, Raymond (2000). »Children's creative collaboration: The importance of friendship when working together on a musical composition «, Social Development, 9(3), str. 348-369.

doi: https://doi.org/10.1111/1467-9507.00130

Morfold, James J. (2007), »Perspectives constructivism: Implications for postsecondary music education and beyond «, Journal of Music Teacher Education, 16(2), str. 75-83. doi: https://doi.org/10.1177/10570837070160020108

Murphy, Regina (2017), »Integrating the primary curriculum«, u: Burnrd, Pamela i Murphy, Regina (ur.), Teaching Music Creatively, 2nd edition, London and New York: Routledge, Taylor \& Francis Group, str. 135-147.

National Advisory Committee on Creative and Cultural Education (1999), All Our Futures: Creativity Culture \& Education. Dostupno na: http://sirkenrobinson.com/pdf/allourfutures.pdf [20. 12. 2018.]

Oblak, Breda (1987), Ustvarjalno učenje v glasbeni vzgoji na stopnji razrednega pouka osnovne šole, doktorska disertacija, Ljubljana: Univerza Edvarda Kardelja, Akademija za glasbo.

Oblak, Breda (2000), »Vpogled v značilne raziskave o ustvarjalnem učenju na področju glasbe«, Glasbeno-pedagoški zbornik Akademije za glasbo, Vol. 3, str. 55-66. Ljubljana: Akademija za glasbo.

Paulus, Paul B. i Brown, Vincent R. (2007), »Toward more creative and innovative group idea generation: A cognitive-social-motivational perspective of brainstorming «, Social and Personality Psychology Compass, Vol. 1(1), str. 248-265. doi: https://doi.org/10.1111/j.1751-9004.2007.00006.x

Predmetni program Muzička kultura (2017), Podgorica: Zavod za školstvo Crne Gore. Dostupno na: http://www.zzs.gov.me/naslovna/programi/osnovno [25. 1. 2019.]

Rhodes, Melvin (1961), »An analysis of creativity«, Phi Delta Kappan, Vol. 42, str. 305-310. 
Rusinek, Gabriel (2016), »Action-research on collaborative composition: Analyses of research questions and deigns «, u: Odena, Oscar (ur.), Musical Creativity: Insight from Music Education Research Musical Creativity: Insights from Music Education Research, 2nd edition, London and New Yotk: Routledge, Taylor \& Francis Group, str. 185-201.

Sternberg, Robert J. i Lubart, Todd (1999), »The concept of creativity: Prospect and paradigms «, u: Sternberg, Robert (ur.), Handbook of Creativity, Cambridge University Press. doi: https://doi.org/10.1017/CBO9780511807916.003

Scott, Sheila (2006), »A constructivist view of music education: Perspectives for deep learning «, General Music Today, 19(2), str. 17-21.

doi: https://doi.org/10.1177/10483713060190020105

Ščevkušić, Slavica G. (2011), Kvalitativna istraživanja u pedagogiji. Doprinos različitih metodoloških pristupa, Beograd: Institut za pedagoška istraživanja.

Wiggins, Jackie H. (1999), »Teacher control and creativity«, Music Educators Journal, 85(5), str. 30-44. doi: https://doi.org/10.2307/3399545

Wiggins, Jackie (2002), »Creative process as meaningful music thinking«, u: Sullivan, Thinoty i Willingham, Lee (ur.), Creativity and Music Education, Toronto: Britannia Printers, str. 78-88.

Wiggins, Jackie H. (2015), Teaching for Musical Understanding, New York: Oxford University Press.

Webster, Peter, R. (2011), »Construction of music learning «, u: Colwell, Richard i Webster, Peter R. (ur.), MENC Handbook of Research on Music Learning. Volume 1: Strategies, Oxford University Press.

doi: https://doi.org/10.1093/acprof:osobl/9780195386677.003.0002

Webster, Peter (2018), Thoughts about Creative Collaborations acros Art Forms. Dostupno na: https://www.isme.org/news/thoughts-about-creative-collaborations-across-art-forms [26. 1.2019.]

\section{COLLABORATIVE CREATIVITY IN ELEMENTARY SCHOOL MUSIC TEACHING}

\section{Jelena Martinović-Bogojević}

The socio-cultural dimension of creativity is an essential aspect of theoretical examinations of the phenomenon of musical creativity. Empirical research and practical experience have resulted in the need to reconceptualise and reinterpret the concept of musical creativity in education. The concept of collaborative crea- 
tivity developed through the socio-cultural context itself. In school practice, collaborative creativity can be achieved among pupils, as well as among teachers who cooperation through integrative teaching, extracurricular activities, and project teaching. This paper will present some ways in which to encourage collaborative musical creativity, with a special view to student experiences and the influence that collaborative creative processes have on their socialisation, motivation, and the practical implementation of acquired knowledge. The action research methodological framework was implemented in a Year 5 elementary school class during the 2017/2018 school year. The goal of the paper is to examine the potential for encouraging collaborative creativity in regular music teaching, as well as to indicate objective difficulties in undertaking this type of creative process in schools.

Key words: collaborative creativity, musical creativity, music teaching, elementary school 